\title{
FUNERAL CUSTOMS OF CAUCASIAN ESTONIANS
}

\section{Marika Mikkor}

\section{Introduction}

Customs characterising a nation or an ethnic group, depend on the stage of development of the society, dominant religion and ethnic environment. In an ethnological study of settlers their origin, time of emigration and national composition of settlements should be taken into account. Of the Estonian villages of Caucasia the village of Estonia was founded in 1882 by the Estonians from the province (guberniya) of Samara, who had left Estonia in the 1850-1860s. The villages of Salme and Sulevi were founded in 1884 and 1885, respectively, by the peasants of Harjumaa, the village of Punase-Lageda was founded in 1886 by Estonians from the NorthCaucasian settlement of Esto-Haginsky, who had left Estonia in the 1870s *1 (Võime 1980, 16-18, 21; Võime 1974, 120, 121). In the second half of the past century, in the conditions of arising capitalism, the first settlers of the villages were peasants whose resettlement was favoured by the tsarist government. In addition to the first settlers, new emigrants kept coming both from different regions of Estonia and from other Estonian settlements in Russia. At the same time, there were also leavers. Within the boundaries of one village there lived, side by side, people from different parishes and counties. Parochial belonging of Estonian settlers would be a separate topic of research. For example, in the village of Sulevi descendants of the peasants from Kuusalu and Rõuge parishes married each other.

Settlements were founded as a result of Russian-Turkish wars in the 1860-70s on the lands abandoned by Abkhazian and Circassian people (Chursin 1956, 194). On the arrival of Estonians the only signs witnessing the one-time presence of the natives who had been killed off or fled to Turkey, were fruit trees running wild and village lanes overgrowing with weeds. The Czarist government populated the conquered lands with Orthodox refugees of the Russian-Turkish wars: Bulgarians, Moldovians, Greeks and Armenian s, who came from Turkey and its spheres of influence (Volkova 1978, 20, 15; Roos 1992, 73-78) and Lutheran economic fugitives: Estonians, Latvians and Germans. Next to the Estonians in Punase-Lageda was a Greek village, the villages of Salme and Sulevi ad joined to Moldovian and Armenian villages, the village of Estonia to Armenian and Bulgarian villages, Ülem-Linda (Upper Linda) to Latvian, German and Greek villages. All these nations were land-tillers.

Until the 1920s the main language of communication between different nations in Abkhazia was Turkish (Volkova 1978, 45), a language the Estonians could not speak. This difference was accompanied by the dissimilarity of religion. That was the reason for th e lack of closer social intercourse with Orthodox peoples. $*_{2}$ The settlements were closed "islands" with Estonian schools, societies and Lutheran traditions. Despite the distance their communication with the native land was quit e lively.

The Soviet regime brought along the ban on ecclesiastical rituals, the establishment of collective households and the closing of Estonian schools in the Estonian settlements of Caucasia in the 19201930s. In 1937 and 1938 many Estonian intellectuals and wealthier proprietors were executed. The end of the 1930s brought along an influx of Armenians of Turkish origin to Estonian villages. In the 1940-50s there was an all-Georgian campaign of the resettlement of mountain tribes to the plains, in the course of which Mingrels and Svaans arrived in great numbers to Estonian settlements in Abkhazia. The mountain tribes, adhering to Eastern Christianity, had until their very resettlement 
retained strong features of the feudal system, and in their native territory they had mainly lived on hunting and cattle-breeding (Volkova 1978, 12, 20-22). *3 The main neighbours of Estonians in the villages of Salme, Sulevi and Estonia were Georgians and Armenians and in the village of PunaseLageda Greeks. Then an economic depression of settlements started.

Gradually more Russians came to settle in the original Estonian villages. Russian became the language of communication between different nations. Common school and work and weakening of religious and language bars promoted mixed marriages, predomin antly with Russians. In most cases the son-in-law or the daughter-in-law came from a faraway place, so that the marriage did not bring along close contacts with another nation as it was the case with Caucasian relatives from the neighbourhood, who were kn own for a particularly keen sense of relationship, owing to which all more distant Estonian relatives of mixed marriages were under considerable influence of Caucasians.

Neighbours of different nations have some influence on each other's customs. Therefore, a change in the customs of settlers can be detected depending, on the one hand, on material, ideological and social conditions and, on the other hand, on ethnic factor s (mutual interaction of Estonians of different regions, neighbours of different nations). The aim of the present article is to find out mutual cultural influences. This is not an easy task, as the customs related to most important events in the people's lives are to a great extent of international character. The comparison is made more complicated by the fact that there is no comprehensive study of Estonian funeral customs (exequies). In Georgia these customs are variegated as tribal differences have pre served there. Armenians and Greeks of these settlements are resettlers from Turkey and from territories influenced by Turkey whose customs have not been studied.

The article is mainly based on the material collected on nine expeditions to Caucasia in 1984-1987 (EA 203, 1-273; EA 207, 181-394; EA 218, 11-63). The material for comparison was collected from Estonia in 1986-1989 (EA 212, EA 213; EA 225; EA 226), Ingermanland and Mordovia (EA 218; EA 220) (Mikkor 1993; Mikkor 1994; Mikkor 1994a, Mikkor 1995).

\section{Death}

In former times nursing of a hopelessly ill person was a common concern both of his/her family and the villagers. People went to see and comfort the dying person, whose condition was relieved by praying. Nowadays it is thought in settlements and also in Estonia that there is no sense in disturbing a hopelessly ill person. Only the next of kin are summoned.

In the course of time it has been noted that dying persons are restless and that they have various wishes as to the whereabouts, food, etc. Often they wish to change the bed or to be lifted on the floor. They have asked to be washed, the door or the window to be opened. *4 Some people gain appetite before death. One of the informants from the village of Estonia told that the dying person must be fed before death, because if a person dies hungry, he/she will start asking for food from the relatives in their dreams (Puusta). It was believed earlier in Estonia that people eating before death foreboded misery and hunger to the survivors. It was feared that disregard of the dying person's wishes might cause haunting. In the settlements the dec eased revealed their discontent through dreams, haunting was mentioned only in sayings, and this was generally feared: "Our Mamma said that those on the sea and those behind the mountains may come back, but never those underground" (Chernyagina). Nowadays the dying person's wishes are fulfilled on ethical considerations. Photo 5

Before death some people start preparing for the departure either in dreams or awake. A woman from the village of Estonia dreamt a few days before her death that her relatives who had died earlier came after her and in her dream she started bundling up her clothes (Puusta). Sometimes 
dying persons express their desire to go home though they are at home. In Estonia and Ingermanland some concrete cases were referred to where the people dying desired to go home and packed their things (EA 212, 185; EA 220, 147-148). Earlier deceased relatives meeting the dying person is an internationally known idea (Loorits 1927; Dzhanashvili 1893; 158; Kemppinen 1967, 26; Vdovin 1976, 246; Gracheva 1976, 51).

On the verge of death the dying person's nose and chin sharpen and eyes become grey. Often they turn their eyes to the wall or look up. Two cases were mentioned where the dying person saw an apparition of a hole in the wall he was afraid of falling into. $* 5$ In the village of Estonia a seriously ill boy saw that his dead father came after him and was walking in the hayloft and the boy was glad about it (Puusta). Empirical observations and religious beliefs are in mutual relation. The descr ibed anxiety, wishes and the appearance of the afflicted person are postmortally interpreted as omens. $\underline{*} 6$

Although the patient has no hope of recovery, it is necessary to secure as fast and painless a death as possible. At the time of dying there should be silence and the name of the person about to die must not be called, otherwise he/she would remain vacillating between life and death for hours or even days. In our days in Estonia silence is often considered the last respect. Beliefs about difficult death of evil people, which have preserved in the settlements until today, were more common in the village of Estonia, while confessing one's misdoings was considered necessary. There were also witches among Caucasian neighbours. A witch had been in great pains before death. Finally he told his son to break open the ceiling boards from the eastern side. After that a big fly flew into the room and flew three times around the room, buzzing loudly, and the old woman died finally (Puusta). Breaking loose the ceiling boards and an image of a soul-insect are known both internationally and in Estonia *7 (Eisen 1926, 255, 256; Raadla 1939, 10). In other settlements the belief about painful dying of sinful people is disappearing more rapidly than in the village of Estonia. Now different diseases are regarded to be the cause of pains. Only some sayings have preserved, such as "You'll be in tortures as you are so wicked that you cannot die", etc.

In connection with expiration and due to Armenian influences the Estonians of the village of Salme cure different diseases with the dying person's hand. At the moment when the person is breathing his/her last, the sore spot is touched with the dying perso n's hand, saying thereby "You are departing now and take my misfortune along" (Sapozhnikova). Healing with the hand of a dead can be found until the present day both in Estonia and in Caucasian settlements, but it is based on the idea of the evi 1 and at the same time healing effect of the corpse, and not on the idea of the departing of the soul as is the case in the village of Salme.

Until now cases of lethargy are remembered in the settlements. It has occurred even that people have been buried alive. As in Estonia and elsewhere (Jung 1879, 114, 115; Haavamäe 1934, 445), when finding an old grave, it has been discovered that \&quo t; the row of buttons is arranged differently", that means that the body has turned the other side in the grave. Sometimes cries of the apparently dead have been heard, but help came too late.

There are two reports about the time of dying from the village of Estonia, according to which a person will die at the same time of the day when he/she was born. The author knows an equivalent belief from the Livonians who thought that a person would die two hours after the time of his/her birth (Loorits 1932, 177).

\section{Washing And Dressing Of The Body}

The eyes and the mouth of the deceased are closed, as in Estonia it was considered a bad omen when they remained open. In the village of Ülem-Linda (Upper Linda) the mouth of a farmer 
remained open, and some time later a baby was born to his son who died soon after birth (EA 218, 57). When needed, coins are placed on the eyelids of the dead and a roll of cloth is put under his/her chin or the chin is tied up with a piece of cloth. The purpose of closing both the eyes and mouth and the following activ ity is today explained from aesthetic outlook. The washing rite is not so thorough any more in Estonia either. In some rare cases, when the deceased had been washed before death, he/she was not washed again. An older practice was washing and dressing of $t$ he person already before death, which could be found in Estonia, Finland and Russia even in the last century (Wiedemann 1876, 309; Salmio 1976, 27; Mashkin 1862, 80; Zelenin 1915, 663; Kotlyarevsky 1891, 210; Zelenin 1927, 320). Initially postmortal washi ng was even regarded as improper. In earlier literature the only notes about the time of the washing of the dead in Estonia were that "as soon as the soul left the body the dead was washed..." (Jannsen 1874, 302). Most of the later data both from Estonia and the settlements state the same. The washing was done promptly, because stiffening of the dead body would have made the dressing complicated. In all settlements in some particular cases it was considered necessary to postpone the washing of the body for some hours, as the deceased was believed to perceive the surroundings for some time after death. Sometimes it was thought that the dead person could perceive the surroundings for a whole day or even during three days (EA 218, 59-60). In most cases the delay of washing was not due to beliefs. $\stackrel{* 8}{ }$ Armenians and Georgians of the settlements wash the dead body only after it has cooled down (EA 207, 387) or on the day preceding the funerals, which is an old tradition *9 (Mamaladze 1893, 77; Dzhanashvili 1893, 159). Consequently, the Estonians living there may have some foreign influence.

Usually the dead were washed by the members of the family or more distant relatives. In some cases, especially in mixed families, close relatives were not allowed to wash the dead. The same ban could also be found sporadically in Estonia *10 (Allik 1970, 58; Lang 1981, 38). According to the information obtained from Estonian settlers, their Caucasian neighbours are strictly forbidden to take part in the preparations for funerals: "But among blacks the relatives must not do anything, they only sit by the coffin day and night and lament, its a question of honour" $* 11$ (Kuldkepp). Earlier washers were older people, today they can also be middle-aged. A man is washed by men and a woman by women, although women may also wash a man. To get rid of the fear for the dead it was necessary to touch the left foot of the dead body (Jakobson). This is a variant of an international tradition (Wiedemann 1876, 477; Zavoiko 1914, 97; Smirnov 1920, 32; Haavamäe 1934, 44; P\&a uml;ss 1939, 198, 199, 203, 219; Juvas, Reponen 1939, 287).

Caucasian Estonians wash the dead mostly on the floor, on old cloths or linen and a wax cloth. Earlier the dead were washed on straws and hay (EA 218, 58), but this has not been practised for a long time. In the villages of Sulevi and Punase-Lageda the de ad bodies are washed on benches. Usually the body is washed in the same room where he/she died. A case has been written down from Sulevi, where the body was washed in the yard (Toomasson), which is said to be a common tradition among Armenians *12 (EA 207, 367). In the settlements of Estonia and Punase-Lageda the bodies are washed with warm water and a soap, in recent decades washers of other settlements have begun to use vodka and spirits for rubbing the dead body. In Estonia the cleani ng of the dead body with spirits spread in the 1930-1940s (EA 225, 447, 521).

Caucasian Estonians do not believe in a harmful effect of the things used for washing the dead body any more. There are some references from different settlements about casting the wash water under a tree or by the side of a fence: "Some threw it in a tree, for its good luck, in a young tree" (Angelstock). It was considered important to avoid going to the place where the water was thrown, without knowing the significance of it. The same was the case with the wash water used for washing a new-bor $\mathrm{n}$ child (Mikkor 1985, 38, 39). The same requirements are known in Estonia and among other nations. At Punase-Lageda the wash water was put in a vessel under the bed of the 
dead. This had to keep the dead body from getting spoiled. This has been done also in some places in Estonia (H IV 4, 338 (9) < Tarvastu; ERA II 138, 579/80 (70) < Hargla). Sometimes the soap that had been used for washing was put into the grave. In the village of Estonia this is done so up to now. In other settlements the soap is thrown away, burnt or dug into the ground, in poorer times the soap was used up. In Estonia the soap was formerly put into the grave or given to the washer. Votes and Russians buried the washing utensils or threw them into a river (Ariste 1974, 151; Zele nin 1915, 909; Zelenin 1927, 321; Zavoiko 1914, 91), Izhorians burnt or buried the utensils (EA 220, 185). The Armenians living in the settlements bury the clothes which the people had on at the moment of death, the Georgians throw them into a river (EA 2 07, 367). The initial aim of these activities was to send the things to the dead and not getting rid of the things.

There is a note from the village of Estonia about the precautionary magic use of the soap used for washing the dead during funerals: "When the dead is carried out from the house, the soap is put on the floor and when people walk across it all quarrel s and bad things quit the house" (Ryabich). ${ }^{*} 13$ In Estonia the soap was also used for different precautionary purposes, e.g. the shirts of a quarrelling man had to be washed with it, so that he would not start fighting (H II 57, $536(31)<$ Järva-Jaani). Corresponding traditions are internationally known.

In some rare cases the soap and the towels used for drying the dead were given to poorer neighbours. Distribution of things left behind by the dead among poor people can often be found in settlements and, as earlier in Estonia, some believe that in the ot her world these things will be at the disposal of the dead. Caucasian and East-Slavonic relatives and neighbours gave corresponding instructions to Estonian settlers.

The washers, who did not belong to the family, got paid for the work. There were great differences in the pay depending on the family and village. In the village of Sulevi this tradition was called "a custom of Oriental nations". In the village of Salme the clothes and other belongings of the dead had to be given to the washer. In Estonia quite recently socks and mittens were given to the washer (Raadla 1939, 18; EA 212, 189), but there is only one report about this tradition followed in the vil lage of Salme. Only rarely has this work been paid for in cash. Nowadays the washer is given purchased materials for dresses and other pieces of clothing, nobody wants to get second-hand things. In the village of Estonia and in Leselidze under the influen ce of Russians and Caucasians a soap and a towel are given to the washer and it is stated that in former times there was no pay for the work. For East-Slavonians handkerchiefs, head-cloths and towels have been the usual presents at christening and wedding (Kotlyarevski 1981, 214), they are of the same importance as mittens, socks and belts are in Estonia (Tedre 1973, 25, 28, 32, 83, 84). *14 Photo 6

The washers dress the dead. The clothes must be correct and according to the wishes of the dead, otherwise he/she may appear in dreams. Usually older women have got their burial clothes ready in time before death. Men do not pay attention to it, but somet imes their wives take care of the grave clothes of their husbands. In general the dead are dressed in their best clothes, less often the clothes are sewn or bought after death. In former times people were buried in wedding or confirmation clothes. Earlier some rules were followed while sewing grave clothes. Nowadays only a few people remember them. Three notes are known from the village of Estonia, which forbid sewing of graveclothes with a sewing-machine. This was motivated only once by saying: "A s ewing-machine was made by the devil" (Ryabich). In Punase-Lageda and Leselidze the same ban was remembered in connection with the sewing of the grave pillowcase. Although this is an international ban (Smirnov 1920, 29; Loorits 1932, 183; Haavamä e 1934, 440; Päss 1939, 212; Kremleva 1980, 23; Maslova 1984, 86), this has rarely been noted in Estonia (RKM II 82, 581 (53) < Torma), but it must have been known more widely here. There are four reports from different settlements about a ban on making a knot in the thread. In two cases it was explained as follows: "Well, it seems as if 
he/she is tied in his/her doings and cannot get on" (Truuman), "Does the knot hold or ..." (Mustkivi). Thus the knot brings only trouble to th e dead. Once again, this is an internationally known conception and custom (Loorits 1932, 183; Smirnov 1920, 29; Kremleva 1980, 23; Maliya 1982, 104). For example, Komis and Izhorians thought that knots would be an obstacle while passing away to the other world (Päss 1939, 211; EA 218, 124; Teryukov 1979, 82), but Votes were of the opinion that knots would trouble the dead body (Haavamäe 1934, 440). Karelians believed that knots would burn the deceased on crossing the river of fire 15 (Juvas, Reponen 1939, 285). Among the Georgians living in the settlements it is forbidden until today to make knots while sewing graveclothes, and in the coffin all buttons must be unbuttoned and shoe-laces must be untied. Earlier the Estonians 1 iving in the settlements were not allowed to hem graveclothes (two notes from Sulevi and one from Salme), which is also a seemingly rare custom in Estonia (ERA II 294, 616/22 (43) < Kihelkonna). Among other nations this demand concerns sometimes gravec lothes and mourning clothes, sometimes only a winding or face sheet (Maslova 1984, 86; Maliya 1982, 104; Smirnov 1920, 29; Volkova-Dzhavahishvili 1982, 140; Harva 1935, 106). In settlements Georgians are still forbidden to hem mourning clothes.

A piece of cloth left over from sewing was sometimes put into the coffin: "Let him sew there the trousers himself" (Jakobson), it was considered important to guarantee the prosperity of the dead. By the present time the Estonians of the settleme nts have forgotten these requirements, while practical considerations and prestige have gained importance.

Formerly graveclothes were made of calico and mostly they were grey. In the 1920-1930s white graveclothes for women could be found in Alam-Linda (Lower-Linda), Ülem-Linda (Upper-Linda) and Leselidze (EA 218, 59). Yet in the 1910s white graveclothes $\mathrm{w}$ ere predominant in Estonia in the county of Viljandi (Reiman 1915, 144). Today both in settlements and in Estonia older people are buried in darker clothes and younger ones in lighter clothes. Black is not used for graveclothes, *16 it i s even avoided. Yet black is characteristic for Caucasians. In the 1950-1960s, under the influence of mountaineer settlers, black became the common mourning colour in Georgia $* 17$ (Volkova 1978; 33, 34; Volkova-Dzhavahishvili 1982, 156), but elsewhere it is said not to be as compulsory as for the mountain tribes. Under the influence of the latter, black spread also to Armenians of the settlements under consideration (EA 207, 369).

Stockings are put on women and socks on men. In some families the dead was left without shoes, which is a ruling custom till today for the Estonians of Punase-Lageda. In other settlements slippers were put into the coffin or on the dead until the 1950s. I $n$ recent decades they were mainly replaced by shoes, which were considered to be more respectable. Hitherto slippers are preferred for women in the village of Estonia. In rare cases high-heeled shoes are put on women, which are not recommendable at all. A deceased woman appeared to her husband in his dream and spoke: "My feet are so sore, I cannot walk in these shoes on a rough road, my feet are aching. In a near-by family an old woman is going to die. Put my shoes on her, then I can get them" ( Puusta). Thus the deceased had to walk a lot in the other world, which is why she worried about her shoes. $* 18 \mathrm{~A}$ similar dream was reported in Ingermanland (EA 218, 209). Caucasians and East-Slavonians of the settlements put shoes on the dead. An Estonian in Sukhum who came from Punase-Lageda buried her son without footwear as it was customary in her native place. Her son started asking in her dreams: "Mama, why didn't you put shoes on me?" (Rootsi). Mother buried the shoes on the spot of the grave, hoping that her son would get them. The woman was married to a Georgian. It was a common tradition among Estonian settlers to send things to the deceased by burying them. It is known that for example Mordvinians, Abkhazians and Izho rians have sent food, presents or some things left behind to their dead relatives by burying them in another grave or putting them in the coffin of the next person to die (Harva 1942, 26, 31; Chursin 1956, 194; EA 218, 198) and this has been noted also by Estonian Swedes living by the sea (Russwurm 1861, 124). 
As a headgear a shawl is put on old women's head, for men often a cap is put into the coffin. In the village of Estonia they forgot to put a cap into the coffin of a young man. The son began to demand his cap from his mother in her dreams, saying that he was cold. In the village the Russian daughterin-law was told to buy a cap and give it to the first person she met (Lindenbaum). Again this is an international belief which has preserved longer among Orthodox nations.

\section{The Corpse At Home}

Before funerals the deceased was kept in an outhouse. In Estonia it was believed that the dead had to be taken out of the house as soon as possible to avoid another death in the family $* 19$ (Allik 1970, 52). Mostly the dead were kept in t he barns as it was done also in Estonia; in the villages of Salme and Sulevi they were kept also in the cellar due to the warm and damp climate. Nowadays the dead is generally kept in the living room, in some cases also on the veranda. It is a rare case $\mathrm{W}$ hen the dead are kept in an outhouse in the villages of Salme and Sulevi. First of all it was in the village of Estonia that they started to keep the dead in the dwelling house where the body was laid in state in the largest room, i.e. "the hall" ; to make it more convenient for the village folk to visit the dead. Other nations of the settlements kept their dead mostly in dwelling rooms until the funerals. These days the dead in Estonia are kept in dwelling rooms, on the veranda and in the outhous e. Sometimes Georgians put up a large plastic or tarpaulin tent in a yard $* 20$ where the body is taken on the day of the funeral or earlier (KV 362, 237, 238). In the tent there are long tables for the funeral feast. Some Estonian mixed f amilies follow the example of Georgians.

The dead body is lying on a firm bed, on benches, chairs or on the boards placed on the bed, covered with a sheet. For Estonians this replaces the bier, which is still used by Armenians in the village of Salme (EA 207, 373). Since the 1950s the Estonians of the village of Estonia, being influenced by neighbours, sometimes use special iceboxes or ice-cases. There is a hole at the bottom of a rectangular wooden case. Ice is put on the bottom of the case and on the corpse. The case is tilted so that when the ice melts the water flows out of the case through the hole. $* 211$ The cases are a common property of the village or several villages. People pay for the use of the cases.

Some reports are known only from the villages of Estonia and Punase-Lageda about the direction in which the dead body is lying. In former times the feet of the body had to be directed to the east or towards the door, the coffin had to be directed along th e house.

The body's hands and feed are tied to keep the limbs better together. Before funerals the limbs are untied, otherwise the dead person may appear in dreams. The same requirement is also known to other nations (Manninen 1924, 12; Suurhasko 1985, 69; Pä ss 1939, 206). In the village of Estonia they forgot to untie the feet of a spinster and she complained in a dream to her sister that all other deceased people were having a good time and dancing, only she had to stand by the wall as her feet were tied (K uutman). Karelians and Mansi dug the grave open when they had forgotten to untie the limbs (Kemppinen 1967, 33; Rombandeyeva 1980, 233). In Estonia, on the other hand, in former times the deceased were buried with tied limbs to avoid haunting (Viluoja 197 1, 18, 19). Caucasian Estonians put the ties into the coffin.

After the body is washed and dressed, rearrangements are made in the whole household. In some families mirrors are covered, less often other reflecting surfaces are covered as well, while the religious idea of the custom has been forgotten both in settlem ents and in Estonia (Viluoja 1971, 45). In most cases people even do not know that this was done so to avoid seeing the reflection of the dead or of the person himself. Covering of mirrors is a sign of mourning. In Estonia it was believed that when a pers on saw the reflection, he/she might die or his/her face might turn yellow

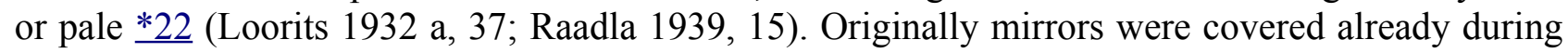


dying, because it was believed that the reflection of a living pe rson may hold his/her soul that may be carried along by the soul of the deceased (Frazer 1974, 253, 254). In some families of the villages of Salme and Sulevi mirrors are not covered, in Leselidze the custom was stated to be new and taken over from neighb ours. In settlements the custom of covering the mirrors is vanishing in some places, while in other places it is livening. In Estonia this custom can be met in northern Tartumaa up to these days, but in many places it is no longer remembered (EA 213, 316, 337, 338; EA 225, 527, 450). Generally this international tradition disappeared earlier among Lutheran nations. $\underline{* 23}$

In the village of Estonia the clock is stopped as a sign of mourning, which is a newer and a more rare tradition in Estonia (Allik 1970, 116; Tedre 1985, 77).

Some of the furniture is taken out of the room where the body is kept, thereby the Estonians of the village of Estonia are more radical. The village folk assists the family of the deceased at chars and in preparing for funerals. Although people are more $\mathrm{h}$ elpful in settlements than in Estonia, in some families only the relatives take care of the preparations. More assistance is rendered to mixed families.

Caucasian Estonians do not remember any special bans on work; however, no big works are undertaken at that time, because of the lack of time. When there is mourning in the village, Russian neighbours must not butcher a pig, do whitewashing or preserve any thing or otherwise "the smell of the dead will stick". It is not recommendable to plant or sow, either, because the plants would not grow. But there was also an opposite belief that it was useful to sow and plant namely on the day of funerals. < A HREF="\#25">*25 Caucasians of the settlements know some bans on work concerning the house of mourning: Armenians must not wash the floor and do the laundry (EA 207, 372,389 ), Georgians were not allowed to wash themselves in the house of mourning, th is can be done only at the neighbour's house across the river. *26 Caucasians were not allowed to make fire in the hearth or to cook in the house where there was a corpse. All these bans were formerly known in Estonia (Wiedemann 1876, 31 0; Waronen 1898, 68; Reiman 1915, 146; Raadla 1939, 36, 37; Eisen 1920, 41). For Caucasians the bans were valid even after the funerals. In the course of a year after death the family was not allowed to stew a chicken, as it was believed that it would scr atch the ground in the eyes of the deceased (EA 207, 372). $* 27$ Photo 4

During the preparations a coffin was procured. A few decades ago they were made in the village, now they are bought from town. Earlier some men used to make the coffin and the cross for themselves during their lifetime, which is said to be "a very ol d tradition". More often the boards for the coffin were provided.

From the village of Estonia the following ban is known in connection with coffin-making: 'A coffin was being made to my neighbour. I said: "God speed you!" The coffinmaker said that when a coffin is being made one should never say "God spee d you!"' (Kuutman). The same ban was known to East-Slavonians: it was forbidden to say 'God help you!' to a coffinmaker or a gravedigger (Zelenin 1914, 157), as it might cause another death in the family.

A soft mattress of wood shavings and a cloth was put into the coffin, the pillow was stuffed with shavings, too. Earlier it was not allowed to use a feather pillow, because "... a feather is warm" (Angelstock). $\stackrel{* 28}{28}$

An informant from the village of Estonia remembered that formerly the cloth for the coffin and winding sheet had to be torn, not cut with scissors: 'it is not good to cut for the dead" (Ryabich). There is a report from Estonia about a similar ban for making graveclothes (H II 27, 229 (8) < Palamuse). This tradition is internationally known (Maslova 1984, 86; Smirnov 1920, 29; Shein 1890, 540; Strogalshchikova 1986, 72; Maliya 1982, 86; Mikkor 1993, 33). 
The remainders of coffinmaking were burnt or put into the coffin. The corresponding religious explanations originate from the village of Sulevi: if the scraps were preserved, the relatives would miss the dead for a very long time (EA 203, 184), the deceas ed may appear in dreams (EA 203, 214), another death may occur soon in the same family (EA 203, 166). Once it happened that the coffin had been made too long, and it was cut shorter. The remaining pieces were put into the coffin, as "it was not seeml y to have them lying about somewhere« (EA 203, 201). In Estonia more deaths were predicted when the coffin was oversized. Estonian settlers got a remedy from Armenians against excessive yearning for the dead - some earth was taken from the bo ttom of the grave and put on the shoulder (EA 203, 184). Earlier this tradition was known also to EastSlavonians and Karelians (Zelenin 1914, 61; Karely 1983, 149; Zelenin 1927, 327). Photo 4

Fire, light and deathwatch offered protection against the evil spirits lurking around the corpse. Settlers have preserved these traditions very differently, depending on the family. Their explanations correspond to contemporary understandings - this tradi tion is followed to express respect for the deceased. Georgians and Armenians, on the other hand, keep the room of the dead lighted before funerals and also three or forty days after the death, believing that the soul that is wandering in the neighbourhoo d might return (EA 207, 370, 389). Deathwatch at night, which was not kept in some Estonian families and which was missing for some time, is beginning to revive as an influence of neighbours. However, some communications state that nightly deathwatch was formerly obligatory, but no longer now. Others state that it is a tradition taken over from neighbours. In most cases the Estonians will sit by the body only up to the nightfall, nightly deathwatch is more characteristic to mixed families. Generally this tradition disappeared earlier at Lutheran nations, but at Orthodox nations it has sporadically preserved to these days. 229 Daily deathwatch is a more recent phenomenon, spreading on the example of the neighbours, and it is also an old i nternational tradition (Sartori 1910, 139). Both in Estonia and also in settlements deathwatch was motivated by the fear that rodents and cats might assail the corpse. Two respondents joked at Punase-Lageda, saying, 'Well I don't know why they used to kee $\mathrm{p}$ watch. I have not dared to ask anybody. Anyway, it's not because they would try to run off' (Mustkivi); 'The corpse, they say, must not be left alone. I wonder why. Evidently because it would stand up and slip away' (Tobias). Such concept of the "l iving corpse" was prevalent in ancient and medieval times, which originally gave rise to the custom of deathwatch (Rimpiläinen 1971, 34). Nowadays it is thought that the deceased may feel lonely. A woman from the village of Estonia told a story revealing an analogy to an international belief which has also spread in Estonia that the devil may creep into the body (Raadla 1939, 29): 'When my brother-in-law died, his sister was there. He had been fond of drinking. The sister told that somebody, like a fire, came, run up the dead body to his head, into his mouth and disappeared. She did not know what to think of it and told the story to me. Russians say that an evil spirit will come and no matter whether you be on the lookout for an evil or a good spirit to appea $r$, you will not see' (Puusta). It appears from this note that Estonians considered deathwatch senseless. Deathwatch was kept by relatives, friends and neighbours. In the daytime relatives sit beside the body. The old custom of eating during deathwatch has almost vanished, today this can be come across only in the village of Estonia. At the beginning of the century peas were eaten during deathwatch in the village of Sulevi where, when speaking about the health of a mortally ill person, it was said that "soon we'll have to start eating peas" (Vuurmann). Eating peas during deathwatch was known also in Estonia and in Finland, where this saying became a symbol of funerals (Varjola 1971, 84). At the beginning of the century sacred songs were sung during deathwatch. At the present time the watchers talk to each other, sometimes they play cards. *30 Sometimes the watchers go to bed in an adjacent room, but sometimes they sleep also in the same room with the body. This is a violation of a demand in folk belief which initially forbade sleeping in the whole house, while the deceased was still at home, later it was not allowed to sleep 
in the same room with the body, so that the soul of the deceased could not take along the soul of the sleeper (Raadla 1939, 29; Frazer 1974, 254).

Following the example of other nations Caucasian Estonians have started to revive the tradition of seeing the dead on the days before the funerals. Meanwhile this tradition was followed only by relatives and closer acquaintances just as in Estonia. There was a somewhat ironic attitude towards the corresponding Caucasian custom: "They kept coming and coming... When a Mingrel dies all the people of the village hurry to the dead even if being barefooted" (Truuman). More often the Estonians went to see the deceased in the village of Estonia and in some families of the village of Salme. Like Caucasians, they kept the door of the house and the gate open all the time the body was at home (EA 207, 370, 388).

When visiting the dead, many Estonians take flowers to the house of mourning. In Estonia formerly small coins were put on the chest of the body, ${ }^{*} 31$ which was a reward for deadwashers and also to cover the costs of funerals (Reiman 1915, 147; Raadla 1939, 30). The custom preserved longer in East Estonia, where finally the money was given only to the poor (Lang 1981, 38). Caucasian Estonians do not remember this custom. However, money is given by the Russian (RKM II 249, 777; RKM II 318, 40), Armenian and Georgian settlers. Estonians consider this to be a custom of "the blacks", i.e. Caucasians. Money-offering spread on Georgian plains at the end of the last century, replacing the practice of giving food, just like in Estonia (Mamaladze 1893, 82; Sagaradze $1899,17)$. At the beginning of the century the custom declined, but in the 1950-60s it revived under the influence of resettlers from the mountains. Armenians of the settlements put the money on the pillow or a plate beside the body, $* 32$ among Georgians the money is collected by a man sitting at the table and writing down all the sums received, because if the same accident happens to the family of the donator, the same sum must be taken to that family. This was the way they acted also in the last century (Mamaladze 1893, 82; Sagaradze 1899, 17). Armenian men give money, women give towels that will be given later to the attendants of the dead (EA 207, 366). The Greek women of the village of Punase-Lageda brought handkerchiefs and towels. The donated money can be spent only for the dead (EA 207, 366). As there are many visitors and everybody brings money, sometimes Georgians are said to have bought a car, a house or some other expensive things, to the great surprise of others (KV 362, 238). In the village of Estonia Georgians collect money also on the occasion of the death of their Estonian friend or colleague, this happens also in mixed families. Estonians have collected money only when some lonely poor person dies, as the lack of money for funeral expenses was considered to be a shame.

When seeing the corpse, Georgians weep loudly, which the Estonians consider to be hypocrisy: 'In former times the black folk used to hire keeners, those walked about with smeared faces. They made awful noises, as if aching badly. But Estonians cry from their hearts' (Jakobson). "When Georgians go to the funerals by car, they keep talking on the way as if being merry, but when they are coming closer to the house they start yelling. The more they yell, the more respectable are the funerals." (Kuldkepp). They look down also on Svaans and Mingrels who scratched their own faces and tore their hair. These are the mourning customs known to many nations since the ancient times, which could also be found among Orthodox Finno-Ugrians. In the last century the "wildness" and "formality" of the mourning traditions of mountaineers were criticized also by Georgian writers (Mamaladze 1893, 81, 82; Sagaradze 1899, 18; Mashurko 1894, 342). Women born in mixed families of Estonians try to follow the tradition of keening. Even behind the fence they still keep talking about how glad the household would be about the large sums of money, but when arriving by the corpse, tears appear in their eyes as if by magic, and they begin to lament in Russian: 'You just were so fair and healthy! Why did you forsake us, etc.' (1785, Estonias). When an Estonian dies, his/her Georgian neighbours do not keen in a loud voice, but keep repeating in Russian: "Oh, good soul! Why did you die... etc.". 
When women went to see the dead they examined the condition and the looks of the corpse. If the deceased was not stiffened it predicted another death in the near future. In the village of PunaseLageda they said that another person would die before 40 days would pass and this would be followed by a third death. The belief is said to be characteristic to Russians, but three successive deaths were anticipated in Estonia, too. According to a communication from the village of Estonia, good looks of the deceased predicted a new mourning in the village, as was the case in Estonia (Allik 1970, 72). Another woman from the same village told that, on the contrary, this would predict good life for the deceased in the other world. In the village of Estonia it was believed that the dead body of a sinful person would taint easily. There was a pious man who used to threaten people with this, but who after death was so festering and swollen that the deathwatchers ran off from the corpse in horror. In Estonia there was abelief that it was the devil that had crept into the tainted corpse, and most probably the devil preferred sinful people. Today the beliefs connected with the condition of the corpse are disappearing. This is due to the modern treatment of the corpse.

Subtropical climate in the settlements calls for greater attention to the preservation of the dead than in Estonia, and in the course of time the corresponding measures have improved. Formerly in hot weather the funerals were arranged as soon as possible. In settlements some substances known in their native land, such as iron, earth, water, sand and salt, were used. *33 In addition, lime and nettles were used as well. There are great differences in the ways and means depending on settlements and families (see Mikkor 1988, 48-50). Iron was put under the bed of the dead body, but also beside and on the stomach of the dead body. Earth, water and lime were placed in a vessel under the bed. Salt and sand were put on the stomach. The effect of all means was explained physically. Earlier many nations believed that iron, earth, salt and water protect from evil, and therefore they were used at birth and on weddings as well.

Estonians learned from their neighbours how to use nettles. They were put on the corpse under the clothes and on the face. From Russian holiday makers the Estonians from the village of Leselidze took over the following practice: a wire is wound around the little finger of the body, the other end of which is shoved into a bucket of earth under the bed. Formerly this was known also in Estonia, e.g. northern Tartumaa and elsewhere (EA 212, 277, 278, 315; RKM II 22, 54 (20) < Räpina). Today the settlers use spirits, ice and formalin, which is injected into the dead body.

The length of the time the deceased is kept at home depends on traditions, preparations for funerals and the season. Generally the settlers buried their dead on the third or fourth day after death. From the villages of Salme and Sulevi there are data indicating that at least up to the 1920 s the dead were sometimes buried on the day following the death, and in one case the funerals took place even on the day of death. Partly it was due to the warmer climate and the lack the watchful eye of the church. Fast funerals on the day of death or the day following it could be come across also in Estonia as late as the past century (Rosenplänter 1823, 36; Winkler 1909, 17; Luce 1827, 101-102).

Beginning from the 1940-50s they started to keep the deceased at home longer, owing to the preparations for more generous funerals, expectation far-away relatives to arrive and also to the improvement of ways of preserving the corpse. Nowadays the dead is at home for three or four days, in rare cases up to six days. The delay of funerals is considered to be a Caucasian custom. Following the old customs of mountaineers, the Georgians of the settlements kept their dead at home from ten days to two weeks. $* 34$ Nowadays, under the pressure of the government, Georgians do not keep their dead at home for such a long period. 


\section{Placing The Dead Body In The Coffin}

Earlier the dead was put into the coffin as soon as possible, on the eve of the funerals at the latest. At the present time more often the dead are placed into the coffin on the morning of the funerals, as it is with other nations. In the past century in Estonia the dead was put into the coffin shortly before going to the graveyard $* 35$ (Reiman 1915,147 ). At the beginning of the present century the morning of the funerals or the night before, or still later the day after the death were considered proper (Reiman 1915, 147; Lang 1981, 41, 42). In the settlements the act has again been put off until a later time.

Up to the 1930s the dead was placed into the coffin in a clerical ceremony, conducted by churchwardens. *36 Later other eloquent village people took over this task. By today clerical ceremonies have predominantly disappeared. First the blessing of the coffin vanished, singing of ecclesiastical songs preserved longer. In these days the dead is lifted into the coffin without special ceremonies. At Punase-Lageda a secular ceremony of placing the dead into the coffin developed, where speeches were delivered and food offered.

The dead is supplied with some objects. The list of things which are put into the coffin has changed both in Estonia and in settlements. Instead of household utensils and other necessities the favorite objects of the deceased are put into the coffin, taking into consideration the likes and wishes of the dead. It has been stated about Estonia that the tradition of putting things into the coffin disappeared here by the beginning of the present century (Moora 1956, 33, 34) or even by the present time (Lang 1981, 44, 45). Actually at places the tradition has preserved in these days too. In settlements tobacco, pipes, cigarettes and strong drinks were put into the coffin for men and handicraft necessities for women. Washing materials, in former times a soap and a sauna whisk, were provided both for men and women (EA 203, 14). In the village of Estonia a handkerchief, a soap and a comb are the most common things put into the coffin. It was as late as in 1982 that in the village of Sulevi on the advice of an elderly Estonian some coins were put into the pocket of the dead so that he could purchase a place in the heaven $* 37$ (EA 203, 215). Middle-aged Estonians regarded this custom with irony and contempt. Even in heaven one cannot get anything without money, they said. For Georgians of the settlements money was the main thing to be put into the coffin. The Georgians supply the dead with strong drinks, cigarets, sweets and great sums of banknotes so that the dead could buy what he would need in the other world. On the other hand, the Armenians were not allowed to put money into the coffin "lest the dead will snatch all your money" *38 (EA 207, 366). Instead, Armenians provide all the best clothes of the dead and a new towel (EA 207, 368). Once even a gun was put into the coffin. Both Russians and Greeks put towels, handkerchiefs and a soap into the coffin. Moldovians and Greeks throw silver coins into the grave and Russians throw copper coins to purchase a place for the dead or to pay the tax for passing the Golden Gates. *39 At Punase-Lageda the Russians have insisted that Estonians should throw money into the grave.

There is a report from the village of Estonia about an ancient demand to put hairs into the coffin (Wiedemann 1876, 478; Eisen 1926, 115). It was not allowed to burn the beard after shaving the dead. It was put into the coffin. It is a wide-spread tradition to put dentures, spectacles, crutches, sticks and the like into the grave.

It was more characteristic for women to express their wishes. They want to take along their dresses, photos. A self-murderer from the village of Sulevi left behind a letter: "Put the violin and bow into my coffin, they will be my husband and child" (EA 203, 80). Men have often asked for a bottle of vodka. In earleir times hymnals were put into the coffin. From the comparison of different settlements it turns out that in the village of Sulevi the wishes of the dead were taken into consideration more often. Due to this, there was a great variety of grave objects. In the village of 
Estonia this tradition is more customary and the main items are handkerchief, towel, soap and comb. Although these things had been put into the coffin both in Estonia and in Finland (Hupel 1777, 155; Talve 1979, 188), in the case of settlers the influence of other nations cannot be ruled out. Following the example of their neighbours, the Estonians of the village of Estonia give the soap and towel to the deadwasher. At Punase-Lageda Russians and Greeks gave a handkerchief to an Estonian dead, but the Estonians are said to have taken it away indignantly. For Orthodox EastSlavonians towels and handkerchiefs were the common things to be put into the coffin, and initially they were considered to be a substitute for money (Kotlyarevsky 1891, 215). Earlier all the objects indicated above were internationally known (Varjola 1980).

\section{Funerals}

\section{Paying The Last Tributes}

Formerly funerals were undertaken at any time. Nowadays public holidays and the so-called "bad « days are not considered proper. Monday is the worst day, Friday and Wednesday are a little better. All these days are internationally known as inauspicious. $* 40$ Older Estonians regarded the forbidden days with doubt, considering them as an influence of the neighbours: 'Nowadays Estonians are aping the other blacks and would not bury, either' (Jakobson), 'Why should Monday berough, it's just sots for whom it may be a rough day.' (Vuurman)

Earlier up to 30 closer relatives and neighbours were asked to the funeral, that was as many people as the family could feed. When the settlements became multinational, only Estonians were asked to the funeral of an Estonian. Neighbours, friends and relatives of other nations came self-invited, as was their custom. *41 Sometimes before death older Estonians express the wish that only Estonians would be asked to come to the funeral. '...But Russians come self-invited. But nobody was thrown out, Russians would also seat themselves at the table' (Reisman). At the present time in mixed families of Estonians and also if a young person has died, people go to the funeral unbidden. Georgians may have from 500 to 1000 people attending the funeral. $* 42$ Under the influence of neighbours the number of people attending a funeral has increased, reaching 200 in Sulevi and 400 in the village of Estonia. There are more people at the funerals of younger people who have more acquaintances and relatives.

As late as last century in Estonia all the village folk came to pay the last tribute, bringing along some food. This tradition preserved longer, when older and more respectable people died. In the course of time the number of people attending the funerals decreased to such a degree that the family of the dead could feed all of them. $\underline{* 43}$

Estonians take flowers to the funerals, other nations take money and towels as it was when they came to see the dead.

In former times food was offered to the people gathered in the house of mourning before taking the dead out of the house. In the villages of Salme, Sulevi and Punase-Lageda they were treated to warm dishes, in the villages of Estonia and Alam-Linda (Lower-Linda), on the other hand, only cold dishes were served in the morning. In the 1930s warm dishes being served before the funerals were predominantly replaced by cold dishes (Moora 1976, 87; Lang 1981, 50-51), but on the island of Saaremaa warm dishes are still being served. Now in the settlements the Estonians offer warm dishes less frequently, this can be come across only in the villages of Sulevi and Leselidze, where this tradition is explained with great distance to the graveyard (EA 203, 77, 78, 270). Today Estonians often consider this tradition alien. Caucasians preserved this old custom until recently (Sagaradze 1899, 17). They thought that in this way the dead would refresh themselves before 
departure (Chursin 1905, 69). In connection with the anti-alcohol campaign in the 1980s the authorities of Georgian government exerted pressure on the custom (Volkova, Dzhavahishvili 1982, 155.) 'And now people in this country are told to feed guests after the funeral. It's because they get drunk and take their cars and drive like mad, and to hell with the corpse. We used to invite the music choir everywhere, to Georgia and Svanetia, and sometimes it happened that the members of our choir had to carry the corpse, all the others were drunk (Kovalenko). We know from history different bans and limitations related to funerals. From the antiquities to the Middle Ages certain demands were put to the number of people attending the funerals, the amount of food and drinks and the duration of the funerals (Rimpiläinen 1971, 30, 123, 187-190, 233, 236, 265; Nenola 1986, 121).

Clerical funerals which had preserved till the 1930s were gradually replaced by secular funeral songs and speeches and the music of a brass band. Singing of ecclesiastical songs at the funerals of older people was still common until recently. Nowadays brass bands are disappearing.

The last tribute is paid either in the room or in the yard. Photo 3Earlier the coffin was closed before taking it out, nowadays it is carried to the graveyard open, as it is with other nations. The cross and the wreaths are carried out first, followed by the lid and coffin. Then come the relatives and other people. Caucasians carry the coffin out last. Before leaving the room, Armenians and Russians lift the coffin three times, Georgians walk three rounds with the coffin, " to make the dead giddy so that he/she will not come back" (Kuutman). This is also the usual procedure at the funerals of Estonians, where the coffin is carried by their Caucasian friends, relatives and colleagues. This internationally known confusing of the dead (Lukkarinen 1914, 2; Chursin 1905, 70; Clemen 1920, 68; Kemppinen 1967, 37) was earlier known in Estonia as well, while in Setumaa it is found even in these days. Photo 8

The dead is carried out feet foremost, as "a man always walks feet first". In some single cases people remembered that this was the procedure to prevent the soul from haunting and to forestall a new death in the family. *44 The coffin is carried very carefully, but the former demand, spread in Estonia, that the coffin should not touch the doorjamb, has been forgotten. Russians and Georgians hit the coffin three times against the doorjamb before leaving the room, Georgians hit it in addition against the closed door to avoid a new death in the family. Caucasians consider it important to close the door and the gates just after the coffin has been taken out, which is also an internationally known demand *45 (Sartori 1910, 143, 144; Päss 1939, 229; Mashkin 1862, 81; Kemppinen 1967, 38).

At the funerals of Estonians the coffin and the cross are mostly carried by male neighbours or relatives. In the village of Punase-Lageda in some families the coffin and the cross were carried by godchildren of the dead, in the case of a female deceased by women. In some places in Estonia the cross was also carried by godchildren (ERM 166, 13 (44) < Reigi). Earlier there was no pay for carrying the coffin and cross in settlements. Caucasians, Greeks and Russians tie a handkerchief or a towel round the carrier's arm as a remuneration. *46 From the $1950 \mathrm{~s}$, under the influence of neighbours, Estonians from the village of Estonia started to give towels, handkerchiefs and shirts to the carriers. In other settlements this is done only in mixed families. The Estonians of PunaseLageda have made some blunders out of ignorance, for instance a woman tied the towel to the wrong arm of the undertaker, at which Russians were annoyed, saying that it was no wedding.

Formerly Estonian settlers carried the coffin on a frame, later it was carried on shoulders or with cloths. When the dead is being carried out, all flowers, wreaths and the leftovers of wreath-making are taken out. Like in Estonia, leaving them behind is an omen of a new death very soon (Raadla 1939, 68; EA 213, 286, 320; Loorits 1932, 196). If the coffin is carried by Caucasians, they walk 
with it three times around the house. This custom to prevent haunting was also known in Estonia (Viluoja 1971, 27).

To a far-away graveyard the coffin was taken in a horse-carriage or on a sledge, at the present time in a lorry. The box of the lorry is decorated with twigs and flowers. Older people or the relatives of the dead take their seats beside the coffin, the others go on foot. Since the 1950s leftovers of wreath-making and flowers are thrown on the way of the funeral procession, while this custom was earlier not known in any settlements. In Estonia it is a tradition to throw spruce twigs on the way, but it is not known when this custom began to spread here. $* 47$ On the way to the graveyard different bans and omens were followed, which only a few settlers can recall. In the villages of Estonia and Punase-Lageda it was thought that to avoid a new death you should not look back when being in a funeral procession or to step in at your own place. The first belief has been noted also in Estonia (Allik 1970, 94) and among Germans *48 (Sartori 1910, 148). In Võrumaa as late a decade ago the relatives of the dead were not allowed to look back on the way to the graveyard as long as the house of mourning was in sight. In the villages of Sulevi and Punase-Lageda it was remembered that the funeral procession should not be looked at through the window (EA 203, 187), but they could not motivate it. Again this is a belief known to other nations (Maris), neglect of this ban could also bring misfortune to the family of the person who looked back (Holmberg 1914, 16; Haavamäe $1934,442)$. In the village of Estonia it was believed that when somebody crossed the road in front of the funeral procession, bumps and lumps would grow on his/her body, which could be cured only with the hand of the dead. At Punase-Lageda the sex and the age of the person to die next were predicted by the person who first met the funeral procession. It was said that once in the village of Estonia a woman with twins in a pram was in the way of the funeral procession, and soon two children perished in a fire accident in the village. At Punase-Lageda the sex of the person to die next was predicted also by the person who passed the cross-carrier. The same prediction is at places still remembered in Estonia (EA 213, 319, 342, 343). In settlements meeting of the funeral procession is considered to be an evil omen. Those who meet the funeral procession will stop and men take off their hats to pay tribute to the dead.

Caretakers remain at home to clean the rooms and lay the tables. In the village of Estonia caretakers accompany the dead halfway and then come back. At Caucasians only relatives go to the graveyard. Besides the practical need, cleaning of the house of mourning has a magical precautionary significance. In the village of Sulevi this is given less importance, but in the village of Estonia, where the cleaning is faster and more thorough, it is more important. In the village of Sulevi they clean the rooms usually only after the return from the graveyard. In all settlements the benches, the bed and the chairs which had been used as bier for the dead, are taken out of the house. In the villages of Estonia, Salme and Leselidze in some families they are turned upside down just after the corpse has been taken out, whereby Estonians regard it as a Caucasian tradition. In the village of Punase-Lageda a fast cleaning is thought to be a Russian custom, and like in the village of Sulevi, they clean after they have returned from the graveyard: 'As soon as the corpse has been taken out, the bucket is ready, everything is washed, lest "neschastie" (the Russian word for 'misfortune') would happen. This is not an Estonian custom. 'When aunt Liisa died, a Russian asked, "Who is going to scrub the floor?" Then I said that my aunt was not of this religion, this is not our way, this is not done in an Estonian village. We locked the door and when Endla came back from the graveyard she did the scrubbing' (Reisman). Photo 7

Orthodox nations of settlements had also dissenting demands not to take the sweepings out at once, they had to be swept into the corner of the room. This was earlier known also in Estonia, keeping of the sweepings was believed to preserve the fortune of the house (Raadla 1939, 47). Turning of the chairs and benches which had served as the bier for the dead to avoid a new death is still practised 
in settlements by Caucasians and East Slavonians. This internationally known custom $* 49$ can be associated with the demand for a speedy wrecking of the bier, which is known also in Estonia (Allik 1970, 56; Lang 1981, 59). In the case of Estonian settlers it is not quite clear whether it is an alien influence or preservation of an old custom in some single families.

\section{The funeral feast}

When the funeral procession arrives at the graveyard, uninvited mourners are already there. If the coffin is carried by Georgians, they walk with it once or thrice around the grave before putting it on the cross-bars or on the edge of the grave, to avoid haunting or a new death in the family (EA 203, 185-186). Earlier this was done also in Estonia (Eisen 1897, 48; Eisen 1920, 165; Viluoja 1971, 83).

In the graveyard a speech is given by a school teacher or a churchwarden and clerical funeral songs are sung. In the villages of Salme, Sulevi and Leselidze at the funerals of Estonians nowadays secular songs are sung and a brass band is playing dirges. Wishes of the dead are also taken into consideration: 'Eduard Vatman, himself a member of the brass band, asked that all kinds of music should be played. They did not play polkas, but they did play waltzes. Afterwards the Georgians said, Estonians dance in the graveyard. Elga Vatman asked that the choir should sing. They would not sing merry tunes, but songs like Good Night, Nightingale's Death, Autumn Morning, are in every collection of funeral songs, even in Estonia' (Kuldkepp).

Before the coffin is shut, relatives come to bid farewell to the dead. One of them spreads a shroud on the face of the deceased. Unlike their neighbours, Estonians leave natural flowers in the coffin. People of other nations often try to insist that before closing the coffin the flowers should be taken out because they may cause a sooner decay of the corpse.

The grave was dug some days or a day before the funerals. As among other nations, in the villages of Estonia and Salme the grave is dug on the day of funerals. Thus an old custom has been reestablished. Digging of the grave as late as possible was believed to prevent the walls of the grave from falling in, which was a bad omen (Allik 1970, 97, 98; Lang 1981, 66). From settlements this belief was remembered only in Estonia: "If the grave caves in, the next person will die very soon in the family" $* 50$ (Ryabich). Often the Estonians had the graves dug by relatives, sometimes close relatives are not allowed to do it. Some food and drinks were taken to gravediggers while they were working. In the village of Estonia, on the example of neighbours, pieces of cloth, shirts and towels are given to the diggers. The Estonians of the villages of Salme and Leselidze have begun to pay money to the gravediggers. Money and treating to food and drinks was the pay to gravediggers in Estonia, too. Instead of towels, mittens were given here.

In most cases the coffin is laid in the grave with ropes, more seldom with towels or straps. In a mixed family at Punase-Lageda the straps were cut to pieces and given to caretakers as souvenir remembrance. In former times in Estonia the coffin used to be let down into the grave with the help of towels.

In the village of Salme in some rare cases the coffin is received in the grave by two men. For this purpose the grave is dug a bit wider and no other means are used. The custom was taken over from Georgian neighbours, whose graves were considerably lower. But there are some communications about receiving the coffin in the grave also in Estonia (ERM 165, 22/(3) $70<$ Jõelähtme; AES Kadrina 1932; RKM II 82, 585 (65) < Torma), more precise data about the spread of this custom have not been found. $* 51$

A wreath or flowers and green twigs are thrown on the coffin in the grave. The mourners throw three handfuls of earth into the grave, whereas only a few remember the Christian origin of the 
custom. According to a popular understanding this helped to forget the deceased sooner and was the last tribute to him or her. On the funerals of Georgians, Armenians and Greeks the mourners hurry away even before the grave is filled up. The Estonians are astonished by this custom. In their opinion this is "savage-like". But from the beginning of the 1960s an analogous communication was found also in Estonia (RKM II 121, 252, 3/(4) < Väike-Maarja).

At the filling up of the grave the Estonian settlers of the village of Sulevi treat the mourners to pies, buns, bread-and-butter, wine and vodka. In the village of Salme this is done later at the gates of the grave-yard. In the village of Salme the custom spread as an influence of Sulevi from the 1930s. By the 1910s the custom was disappearing in Estonia and it was replaced by treating the poor (Eisen 1897: 26; Eisen 1919, 42; Reiman 1915, 158, 160; Raadla 1939, 72; Loorits 1949, 84). In the village of Salme lately a spacious shelter was erected in the graveyard, where funeral feasts were held.

The food that had been taken to the graveyard could not be taken back home. This demand was also known in Estonia. Everything was eaten up in the graveyard or given to the mourners, leftovers of drinks were poured on the ground at the gates of the graveyard. The food left over predicted a new death in the family. Estonians of other settlements were not used to having a meal in the graveyard. Today some Estonian mixed families serve sweets and rice porridge in the graveyard, which is a custom of local East Slavonians. However, most Estonians try to evade porridge-eating even on the funerals of Russians. Up to the present time in Estonia people have a meal in the graveyard in EastEstonia and Setumaa (Lang 1981, 69; Moora 1976, 87). Photo 12

A cross decorated with bands or a wreath is put at the head of the grave. After having decorated the grave with flowers and wreaths, people leave the graveyard. In the villages of Sulevi, Salme and Ülem-Linda by the last person and in the villages of Estonia and Alam-Linda by the first person to leave the graveyard the sex of the next person to die is predicted. The first version was widely spread in Estonia, but Livonians kept an eye on who was the first to leave from the grave (Loorits 1932 , 197). Georgians and Greeks predict death to the last person to leave. It was also believed in Estonia that the last one to leave will bring along death (Loorits 1949, 89).

The mourners head for the house of mourning to a funeral feast. In the yard hands were washed. This was especially important for the neighbours of other nations. In earlier times the Georgians also used to wash their faces (Chursin 1905, 74; Mashurko 1894, 344). Estonians explain this habit just from the aesthetic point of view.

In the villages of Estonia and Salme, on the example of the neighbours, sometimes tents are put up in the yard for the funeral feast. There would not be enough room in the house for several hundred mourners. Following the example of Caucasians, in the village of Estonia it has become a tradition that men and women sit at separate tables, which is again an old custom (Animelle 1854, 144; Shein 1890, 555; Päss 1939, 237; Fedyanovich 1990, 112). On a funeral feast they eat and drink and give speeches. The first course on a funeral feast in Salme and Sulevi was cabbage soup (nowadays borsch and kharcho), in the villages of Estonia and Ülem-Linda chicken soup, at Punase-Lageda cabbage stew. The same dishes were known to be ceremonial in Estonia. For the second course potatoes and meat were served, but in Salme, Sulevi and Punase-Lageda black pudding and jellied meat were served, in the villages of Estonia and Ülem-Linda they served roast pork. During the first course vodka was drunk; wine was served during the second course. As a dessert rice or semolina porridge with fruit jelly or compote was offered and in Ülem-Linda rice soup was served. In Sulevi and Salme buns and pies with coffee (in cold weather) or with fruit jelly (in warm weather) were served. In recent times in addition to Estonian funeral dishes also the dishes of neighbours are served: cabbage rolls, chops, paprika filled with rice, chicken with nut sauce or satsivi, home- 
cooked cheese (sulguni), vegetable salads. In the villages of Salme and Estonia also Caucasian funeral dishes are served: bean porridge (lobia), fried fish and sweet fried macaronis. It is a tendency that new dishes are more often served in mixed families and on the funerals of young people, where there are more people of other nations. In the village of Estonia Estonian dishes have completely been replaced by everyday and funeral dishes of the neighbours. Instead of pork they serve the Caucasian gravy - salyanka - made with tomatoes, onions and paprika. Although it is strictly forbidden for the Georgians of the settlements to eat meat at funerals, $* 52$ they do not refuse it on funeral feasts of Estonians. 'They are always so contemptuous about it. But then they are the first to come to eat meat at Estonian funerals' (Truuman) 'Georgians say, how can you eat flesh when there's flesh (i.e. the corpse) in the house (EA 203, 168-169). The ban on eating meat is not so strict at the Armenians of the settlements, they serve cabbage rolls with meat at a funeral feast (EA 207, 375). It is known that Lutheran nations had to butcher an animal and cook dishes of meat. Armenians of the settlements always had fried fish at the funeral feast, because "it will reach the deceased as quickly as the river current" (EA 207, 375, 378, 379). Georgians do not use knives and forks at the funeral feast (actually they do not use them very often in their everyday life).

In villages funeral dishes are usually cooked by the same women, less often by men. At Caucasians funeral dishes are often cooked by men.

With the funeral feast funerals come to an end.

\section{Summary}

During the past century the disintegration of feudalism had great influence on Estonian national culture, causing gradual recession of traditional customs and lessening of parochial differences. The same tendency was also observed in settlements, where traditions and even the language of the emigrants of different parishes (Vilbaste 1960, Vääri 1960, 425, 428) became similar within one village. Still some older women of the settlements remember various old traditions and for some of them no counterparts have been found in Estonia, but there is no doubt about their Estonian origin (demands for sewing grave-clothes, bans on the way of a funeral procession).

Soviet regime put an end to the reclusion of Estonian settlements with regard to their Orthodox neighbours. It is characteristic to Orthodox nations to preserve their old traditions for a long time, while the reformed Lutheran church exercised greater influence on folk belief. The Mingrels and Svaans who arrived to Estonian settlements in the 1940s and 1950s had preserved remarkable characteristic features of the feudal society and in comparison with earlier Orthodox settlers they had more conservative traditions.

The formation of the settlement of foreign nations with more conservative traditions influenced the development of the national culture of Estonians in another direction. Going to the funerals of the neighbours and relatives of other nations, Estonians come across several phenomena which were earlier known also in Estonia, but which have mostly been forgotten by the present time (collecting money for the dead, confusing of the deceased). Estonians look down on some traditions of the neighbours, especially on keening. In the same way, the neighbours ridicule Estonian funeral traditions. Orthodox and Lutheran world outlooks and different cultural levels come into conflict. Mutual disparaging of neighbours is common to all humanity, this can be met at close nations but also within one nation depending on different regions, villages and families $* 53$ (Westermarck 1991, 83; Oinas 1979, 114).

Orthodox nations of the settlements have a strong influence over Estonians, prescribing even which is the proper way to close the coffin. The influence of other nations on Estonians depends on their 
family ties and also on how many neighbours participate in the ceremony. When a person dies, only close relatives are present, but on funerals there are more people, representatives of other nations among them. Respectively grows their influence on the traditions of Estonians (Mikkor 1992).

Under the influence of the neighbours several traditions forgotten by Estonians have begun to revive, whereby Estonians often consider them to be cultural loans (nightly deathwatch, going to see the dead, covering of the mirrors). An interesting custom is the receipt of the coffin in the grave, some cases of which are known also in Estonia. Most of the cultural loans can be found at the Estonians of the village Estonia (giving towels as a pay for attendants of the funerals, keeping the gates and the doors open before the funerals).

In settlements it is a foreign loan to cast twigs on the way of the funeral procession. It is not always clear whether the settlers have preserved an old tradition or have taken it over from neighbours, such is the case with turning the chairs upside down after the dead has been taken out.

From the elements of material culture, funeral dishes and the substances for the preservation of the dead have been taken over in the first place.

The traditions that had become similar at one time have again become varied due to family ties with other nations. Differences in the speed of development are the most outstanding differences in the settlements. The village of Sulevi seems to be at the stage of forgetting the traditions, while in the village of Estonia the main tendency is the takeover of the customs of neighbours. In the opinion of the author the village of Salme is somewhere inbetween. From the village of Punase-Lageda many cases are known when neighbours have exerted influence on the traditions of Estonians, but the influence of other nations is less than expected. There are no mountaineers among the settlers of Punase-Lageda. A few old regional differences between settlements have been preserved: burying without footwear and cross-carrying by godchildren in the village of Punase-Lageda, stopping of the clocks in the village of Estonia and treating the mourners in the graveyard in the villages of Salme and Sulevi. There are differences in funeral dishes as well. Photo 2

Translated by Tiia Haud

\section{Used sources and materials}

\section{Subject collection and manuscripts}

\section{Estonian National Museum}

EA $=$ Etnographical Archive

EA $126=$ H. Arst. A piecces from the customs of Sukhum Estonians. 1969, 68 - 134

$\mathrm{KV}=$ Answers of Correspondents.

KV $362=$ A. Truupõld. A pieces from the life of Estonians in the former Estonian Caucasian settlements. (Etnographic descriptions) 1980, 117 - 330

\section{Estonian Museum of History}

AM. F. $284=$ Jakob Nerman's collection about Estonian settlements in Caucasus.

AM. F. $309=$ Estonian settlements in the Soviet Union (1895-1983).

\section{Leselidze village Soviet of the Gagra region and Vladimirovka village Soviet of the Gulripshi region of the Abkhaz ASSR}


House registers $=($ Pohozyaistvennaya kniga Nr. 4-9 Leselidzeskogo sel'skogo Soveta narodnyh deputatov na 1983, 1984, 1985 g.) House register No.4-9 of the Leselidze Village Soviet Executive Committee for the years 1983, 1984, 1985).

(Pohozyaistvennaya kniga 9-12 Vladimirovskogo sel'skogo Soveta na 1983, 1984, 1985 g.) House register 9-12 of the Vladimir Village Soviet for the years 1983, 1984, 1985.

\section{Registry Office of the Executive Committee of the People's Deputies of the Gagra region of the Abkhaz ASSR.}

Parish register $=($ Salme Ewangeli Lutteruse Koggodusse kirriku ramat 1885. aastast. $)$ Parish register of the Evangelic-Lutheran Congregation of the village of Salme for the year 1885 .

\section{Collections of the Estonian Literary Museum and Estonian Folklore Archive}

H - folklore collection of J. Hurt, 1860-1906

ERA - folklore collection of the Estonian Folklore Archives, 1927-1944,

RKM - folklore collection of the Estonian Folklore Archives of the Estonian Literary Museum of the Estonian Academy of Sciences, 1945-

ERM - folklore collection of the Estonian National Museum, 1815-1925

AES - folklore collection of Academic Society of Mother Tonque

E - folklore collection of M. J. Eisen, 1880-1934

Allik, E. 1970. Estonian death omens. - Diploma thesis in the Chair of Estonian and Comparative Folklore of Tartu University. Tartu.

Lang, M. 1981. Former funeral traditions in East-Estonia. - Diploma thesis in the Chair of Ethnology of Tartu University. Tartu.

Mikkor, M. 1985. Traditions connected with the birth of an Estonian child in the village of Sulevi, Abkhasia. - Term paper in the Chair of Ethnology of Tartu University. Tartu.

Mikkor, M. 1988. Traditions connected with death at Caucasian Estonians. - Diploma thesis in the Chair of Ethnology of Tartu University. Tartu.

Raadla, A. 1939. An outline of Estonian funeral traditions. I. Seminar paper in the Department of folklore of the Literary Museum.

Sirijos-Giraite, D. 1971. Common traits of cult of the dead in Estonian, Livonian, Latvian and Lithuanian folklore and mythology.- Term paper in the Chair of literature and folklore of Tartu University.

Viluoja, E. 1971. A conception of death in Estonian folk beliefs. Precautions against revenants. Diploma thesis in the Chair of literature and folklore of Tartu University.

(All term papers and diploma thesis are in Estonian)

\section{References}

Animelle, N. 1854. Byt belorusskikh krestyan. - Etnograficheski Sbornik, izdavaiemyi Imperatorskim Russkim Geograficheskim Obshchestvom, vyp. II. Sankt-Peterburg, p. 111- 268. Ariste, P. 1974. Vadjalane kätkist kalmuni. Tartu. Balov, A. 1898. Bolezni i ikh lechenie; smert, pohorony i pominki; zagrobnaya zhizn. Etnograficheskoe Obozrenie, 4, p. 86-92.

Boecler, J. W., Kreutzwald, Fr. R. 1854. Der Ehsten abergläubische Gebräuche, Weisen und 
Gewohnheiten von J. W. Boecler. Mit auf die gegenwart Bezüglichen Anmerkungen beleuchtet von Dr. Fr. R. Kreutzwald. St. Petersburg.

Bogoslavski, P. S. 1924. Materialy po narodnomu bytu, fol'kloru i literaturnoi starine. Permskiy kraievedcheski sbornik, vyp I. Perm, p. 70 - 83.

Clemen, C. 1920. Das Leben nach dem Tode in Glauben der Menschheit. Leipzig, Berlin. Dzhanashvili, M. 1893. Kartvel'skiya poverya. Sbornik Materyalov dlya Opissaniya Mestnostei i Plemen Kavkaza, vyp. 17, 144-173. Tiflis.

Eisen, M. J. 1897. Kodukäijad. Katse nende loomu seletuseks ja 40 juttu surnute hingede ilmumisest. Narva.

Eisen, M. J. 1919. Eesti mütoloogia I. Tartu.

Eisen, M. J. 1920. Eesti uuem mütoloogia. Tallinn.

Eisen, M. J. 1926. Eesti vana usk. Eesti mütoloogia IV.

EKST, Nr. 21. Tartu.

Fedyanovich, T. P. 1990. Pohoronnye i pominal'nye obryady Mordvy. Bytovaya kul'tura Mordvy. Saransk, p. 96-125.

Fieandt, K. v. 1932. Vanhan Sammatin kansanomaisesta kalenterista. (Ajanlaskutapoja, juhlapäivia, ilman ennustuksia). Kotiseutu, 24-42.

Frazer, J. G. 1974. The Golden Bough. A Study in Magic and Religion.

Georgadze, D. G. 1977. Kul't mertvykh v gornoi Vostochnoi Gruzii (po etnograficheskim

materialam). Avtoreferat dissertatsii na soiskanie uchenoi stepeni kandidata istoricheskikh nauk. Tbilisi.

Gracheva, G. N. 1976. Chelovek, smert i zemlya mertvykh u nganassan. Priroda $i$ chelovek v religioznykh predstavleniakh narodov Sibiri i Severa. Leningrad, p. 44-46.

Haavamäe, A. 1934. Vatjalaisia kuolemaan ja hautaamisen liittyviä tapoja ja uskomuksia. Virittäja, 435-446.

Harva, U. 1935. Varsinais Suomen henkistä kansankulttuuria. Varsinais-Suomen historia III:1. Porvoo.

Harva, U. 1942. Mordvalaisten muinaisusko. Suomensuvun uskonnot 6. Porvoo, Helsinki.

Harva, U. 1948. Suomalaisten muinaisusko. Suomensuvun uskonnot 7. Porvoo, Helsinki.

Holmberg, U. 1914. Tsheremissien uskonto. Suomensuvun uskonnot 5. Porvoo.

Hupel, A. W. 1777. Topographische Nachrichten von Lief und Ehstland. II. Riga.

Hämäläinen, A. 1930. Beiträge zur Ethnographie der Ostfinnen. Suomalais-ugrilaisen Seuran Aikakauskirja XLIV, 1. Helsinki, p. 1-160.

Jannsen, J. W. 1874. Mõned vanad Läti ja Eesti rahva pruugid surnute matmise juures. Eesti Postimehe lisaleht. Nr. 50, 51, 52.

Jung, J. 1879. Eesti rahva vanast usust, kombedest ja juttudest. Kodumaalt, nr. 6. Tartu. Juvas, M., Reponen, A. 1939. Kuolemaan liittyviä tapoja ja uskomuksia. Kansantieteellisiä muistiinpanoja Ilomantsin itäkylistä. Kansantieteellinen arkisto III, Forssa, p. 283-293.

Karely 1983: Karely Karel'skoi ASSR. Petrozavodsk.

Kemppinen, I. 1967. Haudantakainen elämä karjalaisen muinaisuskon ja vertailevan uskontotieteen valossa. Karjalan Tutkimusseuran Julkaisuja 1. Helsinki.

Konkka, U. 1985. Ikuinen ikävä. Karjalaiset riitti-itkut. Suomalaisen Kirjallisuuden Seuran Toimituksia 428. Helsinki.

Kotlyarevski, A. 1891. O pogrebal'nykh obychayakh yazycheskikh slavyan. Sochineniya A. A. Kotlyarevskago. t. III .Sbornik Otdeleniya Russkago Yazyka i Slovestnosti Imperatorskoi Akademii Nauk, t. XLIX. Sankt Peterburg, p. 1-296.

Kremleva, I. A. 1980. Pohoronno-pominal'naya obrjadnost russkogo naselenia Permskoi obl. Polevye isledovaniya instituta Etnografii. Moskva, p. 21-30. 
Loorits, O. 1927. Liivi rahva usund. II. Tartu.

Loorits, O. 1932. Der Tod in der livischen Volksüberlieferung. ÕES Toimetised XXVI, Tartu, p. 170-200.

Loorits, O. 1932a. Eesti rahvausundi maailmavaade. Tartu.

Loorits, O. 1949. Grundzüge des estnischen Volksglaubens. I. Lund.

Luce, J. W. L. 1827. Wahrheit und Muthmassung, Beytrag zur ältesten Geschichte der Insel Oesel. Pernau.

Lukkarinen, J. 1914. Inkeriläisten vainajainpalveluksesta. Kansatieteellisiä tutkielmia. Suomalaisugrilaisen Seuran Toimituksia XXXV:7. Helsinki, p. 1-18.

Malija, J. M. 1982. Odezhda abhazov. Odezhda i zhilishchshe abhazov: Materialy dlya istorikoetnograficheskogo atlasa Gruzi. Tbilisi, p.5-126.

Manninen, I. 1924. Setude matusekommetest. Eesti Keel III, p. 10-19.

Mamaladze, G. 1893. Narodnye obychai i poveriya guriitsev. V dvukh chastyakh. Sbornik Materyalov dlya Opisaniya Mestnostei i Plemen Kavkaza, vyp. 17, Tiflis, p. 15-123.

Maslova, G. S. 1984. Narodnaya odezhda v vostochnoslavyanskikh traditsionnykh obychayakh $i$ obryadakh XIX-nachala XX v. Moskva.

Mashkin. 1862. Byt krestyan kurskoi guberni Obojanskago uyezda. Etnograficheski Sbornik, vyp. V, p. 1-119.

Mashurko, M. 1894. Iz oblasti narodnoi fantazi i byta Tifliskoi i Kutaiskoi gub. Sbornik Materyalov dlya Opisaniya Mestnostei i Plemen Kavkaza, vyp. 18, Tiflis, p. 228-410.

Melik-Shahnazarov, J. 1893. Iz poveri, predrazsudkov i narodnykh primet armjan Zangezurskago uyezda. Sbornik Materyalov dlya Opissaniya Mestnostei i Plemen Kavkaza, vyp. 17, p. 193-201.

Mikkor, M. 1992. Kaukaasia eestlaste matusekombestikust. Eesti Rahva Muuseumi Aastaraamat 39. Tartu, 167-188.

Mikkor, M. 1993. Surmaga seotud kommetest ersamordva külades Saba jevos ja Povodimovos. Eksperimentaalne folkloristika. Tartu, p. 32-35.

Mikkor, M. 1994. Surmaga seotud tavadest ersamordva külades Sabajevos ja Povodimovos. Eesti Rahva Muuseumi Aastaraamat 40. Tartu, p. 153-189.

Mikkor, M. 1994a. Kaukaasia eestlaste surmakujutelmadest. Akadeemia, p.1234-1267, 1481-1496

Mikkor, M. 1995. Soikkola isurite matusetavad. Akadeemia, p.1889-1926.

Mikkor, M. 1996. Linnud, loomad, ebaselge päritoluga hääled ja unenäod surmaennetena kaukaasia eestlastel. Eesti Rahva Muuseumi Aastaraamat 41, Tartu, pp. 167-181.

Moora, H. 1956. Eestlaste muistsest usundist. Religiooni ja ateismi ajaloost Eestis. Tallinn, p. 7-42.

Moora, A. 1976. Tavandi ja peotoitudest eesti külas. Etnograafiamuuseumi Aastaraamat XXIX .

Tallinn, p. 47-100.

Narody mira 1962 = Narody mira: Etnograficheskie ocherki. Narody Kavkaza, t. III. 1962. Moskva.

Nenola, A. 1986. Miessydäminen nainen. Naisnäk"kulmia kulttuuriin. Tietolipas 102. Helsinki. Oinas, F. J. 1979. Naabrid ja võõrad keeles ning rahvaluules. Kalevipoeg kütkeis. Toronto, p. 97116.

Ollila, R. 1932. Kuolemaan liittyvät tavat ja käsitykset entisajan Sammatissa. Kotiseutu. p. 87-94. Paulaharju, S. 1924. Syntymä, lapsuus ja kuolema. Vienan Karjalan tapoja ja uskomuksia.

Kalevalaseuran julkaisuja 2. Porvoo.

Päss, E. 1939. Death, burial and life beyond the grave with the Estonian Ingers and the Votes.

Opetatud Eesti Seltsi Aastaraamat. 1937, No II. Tartu, p. 193-259.

Reiman, H. 1915. Eestlaste matusekombed. Eesti kultura. IV. Jurjev, p. 123-163.

Rimpiläinen, O. 1971. Läntisen perinteen mukainen hautauskäytänt" Suomessa ennen Isoavihaa. 
Suomen Kirkkohistoriallisen Seuran Toimituksia 84. Helsinki.

Rombandeyeva, J. I. 1980. Pogrebal'nyi obryad Sygvinskikh mansi. Semeinaya obrjadnost narodov Sibiri. Moskva, p. 232-238.

Roos, A. 1992. Jumalaga, Kars ja Erzurum. Türgi eestlaste ajalugu. Tallinn.

Rosenplänter, J. H. 1823. Ueber Kirchk"fe und Beerdigung der Todten, nebst einem Anhange den Pernauschen Kirchhof betreffend. Pernau.

Russwurm, C. 1861. Sagen aus Hapsal, der Wiek, Ösel und Run". Reval.

Ränk, G. 1949. Die Heilige Hinterecke im Hauskult der V"lker Nordosteuropas und Nordasiens.

FFC 137, vol. LVII. Helsinki.

Sagaradze, M. 1899. Obytshai i verovania v Imereti. SMOMPK, vyp. 26, p. 1-46.

Salmio, L. 1976. Kuolinhetken toimet Länsi-Suomessa. Kotiseutu, p. 24-32.

Sartori, P. 1910. Sitte und Brauch. Handbücher zur Volkskunde. Bd. 5. Leipzig.

Shangina, I. 1984. Prilozhenie. Obryadovaya odezhda vostochno-slavyanskikh narodov v sobranii Gosudarstvennogo muzeya Etnografii narodov SSSR. Maslova, G. S. 1984. Narodnaya odezhda v vostochnoslavyanskikh traditsionnykh obychayakh i obryadakh XIX-nachala XX v. Moskva, p. 156213.

Shein, P. 1890. Materialy dlya izuchenia byta i yazyka russkago naselenia Severo-Zapadnago kraya. T. 51, ch. 2, nr 3. SORJAS.

Smirnov, V. 1920. Narodnye pohorony i prichitaniya v Kostromskom kraye. Kostromskoye Nauchnoe Obshtshestvo po izutsheniu mestnogo kraya, vyp. XV. Vtoroi Etnograficheskii sbornik. Kostroma, p. 21-126.

Strogalshchikova, Z. I. 1986. Pogrebal'naya obryadnost vepsov. Etnokul'turnye protsessy v Karelii. Petrozavodsk, p. 65-85.

Suurhasko, J. J. 1985. Semeinye obryady i verovania karel, konets XIX - nachalo XX b. Leningrad. Talve, I. 1979. Suomen kansankulttuuri. Historiallisia päälinjoja. Helsinki.

Tedre, Ü. 1973. Eesti pulmad. Lühiülevaade muistsetest kosja- ja pulmakommetest. Tallinn.

Tedre, Ü. 1985. Elutähtpäevadest ja nendega seotud kombed. Vanadest Eesti rahvakommetest kaasaesete tavanditeni. Tallinn, p. 37-80.

Teryukov, A. I. 1979. Pogrebal'noi obryad pechorskikh komi. Polevye issledovania instituta Etnografii 1977. Moskva, p. 80-86.

Chursin, G. F. 1905. Narodnye obychai i verovania Kakhetii. Zapiski Kavkazskago otdela Imperatorskago Russkago Geograficheskago Obshchestva, kn. XXV, vyp. 2. Tiflis.

Cshursin, G. F. 1956. Materialy po etnografii Abhazii. Sukhumi.

Ustinova, M. J. 1980. Semeinye obryady latyshskogo gorodskogo naselenia v XX v. (po materialam gorodov Latgale i Kurzeme). Moskva.

Varjola, P. 1971. Hautajaisrokka. Suomen Museo. 78, p. 84-104.

Varjola, P. 1980. Vainajan matkavarusteista. Kotiseutu, p. 118-126.

Waronen, M. 1898. Vainajainpalvelus muinaisilla suomalaisilla. Helsinki.

Vdovin, I. 1976. Priroda i chelovek v religioznykh predstavleniakh chukchei. Priroda i chelovek $v$ religioznykh predstavleniah narodov Sibiri i Severa. (vtoraya polovina XIX - natshalo XX v.)

Leningrad, p. 217-253.

Westermarck, E. 1991. Tapojen historiaa. Kuusi akadeemista esitelmää pitänyt Turussa syksyllä 1911. Suomalaisen Kirjallisuuden Seuran Toimituksia 545. Helsinki, Jyväskylä.

Wiedemann, F. J. 1876. Aus dem inneren und äusseren Leben der Ehsten. St. Peterburg. Vilbaste, G. 1960. Kaukaasia eestlaste keelest ja rahvaluulest. Emakeele Seltsi Aastaraamat VI. Tallinn, p. 121-131.

Winkler, R. 1909. Der estländische Landkirchenvisitator David Dubberch und seine Zeit (15841603). Ein Beitrag zur estländischen Kirchengeschichte. Reval. 
Virtaranta, P. 1961. Tverin karjalaisten entistä elämää. Porvoo-Helsinki.

Volkova, N. G. 1978. Etnicheskie protsessy v Gruzinskoi SSR. Etnicheskije i kul'turno-bytovye protsessy na Kavkaz'e. Moskva, 3-61.

Volkova, N. G.; Dzhavahishvili, G. N. 1982. Bytovaya kul'tura Gruzii XIX-XX vekov: traditsii i innovatsii. Moskva.

Vuorela, T. 1977. Suomalainen kansankulttuuri. Porvoo-Helsinki-Juva.

Väisänen, A. O. 1924. Syntymä, lapsuus ja kuolema. Setukaisten tapoja ja uskomuksia.

Kalevalaseuran vuosikirja, 4, 193- 223.

Vääri, E. 1960. Kaukaasia eestlaste keelest. Keel ja Kirjandus nr. 7, p. 425-429.

Võime, L. 1974. Eesti asustuse kujunemine Abhaasias (Salme ja Sulevi eesti asundused) XIX saj. 80-ndail aastail. Ajalooalaseid t"id. V. (ÜTÜ ajalooringi kogumik.) Tartu, p. 108-121.

Võime, L. 1980. Tee uude ellu. Eesti asunduste ajaloost Kaukaasia Musta mere rannikul XIX saj. teisest poolest kuni 1929. Tallinn.

Zavoiko, F. K. 1914. Verovaniya, obryady i obychai velikorossov Vladimirskoi gubernii.

Etnograficheskoe obozrenie, kn. CIII-CIV. n. 3-4. Moskva, p. 81-178.

Zelenin, D. K. 1914. Opisaniye rukopisei Uchenago Arhiva Imperatorskago Russkago

Geograficheskago Obshchestva. vyp. I. Petrograd.

Zelenin, D. K. 1915. Opisanie rukopisei Uchenago Arhiva Imperatorskago Russkago

Geografitsheskago Obshtshestva. vyp. II.

Zelenin, D. 1927. Russische (Ostslavische) Volkskunde. Berlin-Leipzig.

\section{Comments}

1 The article also contains some observations about the villages of Alam-Linda, Ülem-Linda and Leselidze.

2 The Estonians from the village of Ülem-Linda had closer connections only with their German and Latvian neighbours.

3 Capitalism arose in the Georgian flatlands in the second half of the previous century, as it did in Estonia.

4 In Estonia the dying person was lifted to the floor to make the dying easier (Luce 1827, 101; Boecler, Kreutzwald 1854, 67; Wiedemann 1876, 309). This was done even quite recently, upon the wish of the person (EA 212, 188). In Estonia the door and the window were opened to let the soul out. A more recent tradition was to open the window after death (EA 212, 349). Caucasian Estonians do not remember such beliefs, but Armenians and Georgians open the window for the leaving soul.

5 Many nations used to bore a hole in the wall to ease the escape of the soul (Zelenin 1927, 321). Karelians explained the upward glance of the dying person so that he/she was trying to see the relatives who had died earlier and were now waiting at the head of the bed (Ränk 1949, 46; Salmio 1976, 25).

6 About the death omens from the surroundings (birds, animals, sounds of unknown origin) at Abkhazian Estonians, see Mikkor 1996, 167-181.

7 In Georgian folk belief the soul was carried away by a butterfly (Dzhanashvili 1893, 159). EastSlavonians thought that the evil spirits, waiting for the soul of a witch, would leave through a hole in the ceiling, taking along the leaving soul (Zelenin 1927, 320, 321; Shein 1890, 570).

8 The Izhorians also used to wait a couple of hours before washing the dead (Päss 1939, 202; EA 218, 207). About Finland it is said that the corpse was not washed until it had stiffened (Harva 1935, 105). 
9 At some places in Georgia the deceased was washed immediately after death (Georgadze 1977, 6).

10 In Finland the deceased was mostly washed by members of the family (Talve 1979, 187).

11 On Georgian plains this requirement was not so strict. At Abkhaz people in former times the dead were washed by relatives (Chursin 1956, 186).

12 Also Maris have washed their dead in the yard on straws (Hämäläinen 1930, 134).

13 South-Slavonians had an analogous procedure of preventive magic. They put an axe on the threshold so that the mourners stepped over it while taking the deceased out of the house (Kotlyarevski 1891, 224).

14 At some places in Georgia caretakers were given some wool and knitted socks (Georgadze 1977, $10)$.

15 Initially it was considered important to undo all knots of the dying person's clothes before death, so that the soul could leave freely (Frazer 1974, 320; Karely 1983, 147).

16 The black colour is a recent German loan (Loorits 1949, 74), which spread through urban culture first to mourning clothes, later to graveclothes. In Germany the main mourning colour was black, but white, red and blue were used too (Sartori 1910, 156). In Estonia they have not studied in detail the colour of graveclothes and mourning clothes. Black is often regarded more common, but in northern Tartumaa as late as in the 1980s some old women made a light-coloured gravedress for themselves (EA 225, 396; EA 213, 332).

17 Earlier white was also the colour of mourning in West-Georgia (Volkova, Dzhavahishvili 1982, 140; Maliya 1982, 102, 103).

18 This was also stated by the Finnish researcher U. Harva (Harva 1948, 489), whose point of view was called erroneous by J. Suurhasko. In his opinion they strove to achieve a for as archaic as possible (Suurhasko 1985, 67, 68, 129). Obviously both points of view are correct.

19 In Georgia the dead was taken out of the house as soon as possible, to avoid desecration of the house (Mashurko 1894, 343); earlier this was done already when the person was dying (Georgadze 1977, 6; Volkova, Dzhavahishvili 1982, 141).

20 In Mingrelia in the past a large wattled building was erected in the yard for the dead. This building housed about a hundred mourners (Volkova, Dzhavahishvili 1982, 151). By way of comparison, it is interesting to point out that for example Livonians erected a tent made of fabric just under the windows of the house. The dead was taken into this tent on the eve of funerals (Loorits 1932, 188).

21 We can see some analogy when comparing the box to a Caucasian cradle, which has a hole at the bottom for the excrements of the child.

22 In the village of Sulevi it was believed that if an expectant mother looked at the dead her baby was born with a pale, yellowish or ghastly face (Mikkor 1985, 17, 18).

23 In Ingermanland Lutheran Finns had no tradition of covering the mirrors (EA 220, 150) and at Latvians it was considered to be a Russian influence (Ustinova 1980, 141).

24 Initially the clock was stopped before death (Salmio 1976, 28; E 83430 (7) < Pärnu).

25 In Latvia all plants and seeds were taken out of the house so that the dead could not deaden them (Sirijos-Giraite 1971, 6).

26 It was believed that the soul of the dead cannot cross the river.

27 At Armenians field work and digging were forbidden when the dead was at home (Narody 1962, 532).

28 Initially the feather pillow was removed already while the person was dying. It was thought that the soul may get entangled in feathers (Paulaharju 1924, 70; Salmio 1976, 29; Zelenin 1927, 320). A more recent tradition was to avoid using a feather pillow for the dead (Sartori 1910, 126; Konkka 1985, 56). Till the present time the feather pillow is removed in Mordovia (Mikkor 1993, 33). 
29 After reformation with the help of ecclesiastical laws pressure was exerted on nightly deathwatch in Finland and by the beginning of this century this tradition was limited only to the last night or the eve of funerals (Rimpiläinen 1971, 241; Ollila 1932, 90; Vuorela 1977, 624; Talve 1979, 188). In Estonia, e.g in northern Tartumaa the nightly deathwatch disappeared in the 19301940s, in other places it had been forgotten even before that (EA 213, 280; EA 225, 488). Also in Ingermanland Lutheran Finns did not remember this tradition (EA 220, 149).

30 About playing the cards during the deathwatch see Sartori 1910, 139.

31 Also in Latvia (Hupel 1777, 190).

32 In Finland the money was collected at funerals into a plate (Ollila 1932, 92).

33 The author knows just one case, when the salt was placed on a plate under the coffin (RKM II 3 , 77 (7) < Kärla). Salt was used by Votians and Izhorians (Haavamäe 1934, 438; EA 218, 176).

34 At some places in Georgia the dead were buried on the day of death or next day. On Georgian plains it was common to bury on the $3^{\text {rd }}$ or $4^{\text {th }}$ day.

35 In Mordovia the deceased were taken on biers halfway to the graveyard and only there they were put into the coffin (Harva 1942, 29).

36 According to L. Võime the settlers had accepted secular traditions already by 1924 (Võime 1980, 142). According to the author's data former churchwardens acted at least up to the 1930s (AM. F. 309, N.1.S. 22, L.4p.).

37 Money has been put into the coffin also in Estonia in the 1980s (EA 213, 338, 340).

38 In Vorumaa luck in financial matters was expected for the mourners if they put money in the coffin (Kirk). Both beliefs are internationally known and earlier it was in some places of Estonia forbidden and in some places it was namely recommended to put wool and linen in the coffin for this purpose.

39 According to P. Varjola the casting of money into the grave is an eastern tradition and the putting of money in the coffin is a western tradition (Varjola 1980, 121). Actually the so-called eastern nations have done both (Zelenin 1927, 323; Balov 1898, 88; Shein 1890, 530, 541; Dzhanashvili 1893: 159; Bogoslavski 1924, 75).

40 For Georgians Monday was the worst day, then comes Wednesday (Mashurko 1894, 274), for Finns the worst days were Wednesday and Friday (Fieandt 1932, 29). On these days it was not allowed to bury the dead and to start a new work. Izhorians were also forbidden to have funerals on Mondays and Wednesdays (EA 218, 178).

41 On Georgian plains written invitations to funerals were sent (Mamaladze 1893, 75).

42 At the turn of the century about two hundred mourners participated in the funerals of Svaans and Mingrels, but at some places in Georgia only some twenty or thirty people took part in the funerals (Volkova, Dzhavahishvili 1982, 144, 147, 149).

43 Also on Georgian plains the tradition of taking the food disappeared by the beginning of this century and the number of people participating in the funerals was small.

44 The bridegroom had to carry the bride in his arms out of her home feet first lest she would return home (Veisman).

45 There was also an opposite demand that the doors and gates had to be open during the funerals (Kotlyarevski 1891, 229; Strogalshchikova 1986, 76).

46 Germans presented the carriers with white gloves and handkerchiefs (Sartori 1910, 142). In Latvia mittens were tied to carriers' sleeves (Ustinova 1980, 143), Russians gave them kerchiefs (Shangina 1984, 205).

47 In the village of Uus-Estonia (New-Estonia) in Kuban, Russia, Estonians do not follow this tradition even these days (EA 203, 271). 
48 Several nations know the ban on looking back towards the churchyard when returning home (Smirnov 1920, 34; Melik-Shakhnazarova 1893, 200; Chursin 1905, 71, Juvas-Reponen 1939, 291; Talve 1979, 191)

49 Germans, Finns, Setus, Karelians and Latvians turned the chairs and tables upside down (Sartori 1910, 143; Waronen 1898, 93; Väisänen 1924, 216; Konkka 1985, 58; Vuorela 1977, 624; Ustinova 1980, 142; Virtaranta 1961, 260).

50 In the villages of Sulevi and Punase-Lageda as well as in Estonia a new death was predicted from the caving in of the grave soon after funerals (Allik 1970, 99; EA 225, 455).

51 This custom has been observed also at Vepsians (Strogalshchikova 1986, 74) and today it is found at Mordovians.

52 Not everywhere in Georgia it was forbidden to eat meat at funerals, Lenten dishes were sometimes eaten at the funerals of young people (Volkova, Dzhavahishvili 1982, 144, 150). Meat was not served at other Orthodox nations sometimes only during the Lent. A strict ban on eating meat was seldom observed (Shein 1890, 527).

53 In Estonia "dark" people were mistrusted in former times, people were afraid of their evil eye (Loorits 1932a, 21; Eisen 1926, 96). 